\title{
Liability of Custody for Minor Children from Divorced Family Yunpeng Gao
}

\author{
Law School, University of Jinan, Ji'nan, 250022, China
}

Keywords: Divorced family; minor children; liability of custody

\begin{abstract}
With the continuous transformation of social concept, the divorce phenomenon has been accepted by the masses and the the divorce rate in China rises gradually. Divorce is the freedom and right of both men and women, but the divorce of parents may affect the children's interests in the family with minor children. The system with regard to the custody of minor children after divorce of parents must be perfected to provide reliable guarantee for the minor children from divorced family and ensure the healthy growth of minor children.

Recently, the divorce rate in China is higher and higher, in which the custody problem of minor children is often involved because the physical and mental development of minor children is not mature and may be harmed to affect their healthy physical and metal growth. Therefore, in the divorce case, the interests of minor children must be stressed. To effectively protect the legitimate interests of minor children, great attention should be paid to the healthy development and future development of minor children, the legal custody strength should be strengthened and the liability of custody should be perfected to ensure the healthy physical and mental growth of minor children.
\end{abstract}

\section{Significance of custody system of minor children from divorced family}

In today's society, both men and women have the freedom and right of spouse choosing as well as marriage and divorce. The divorce and remarriage phenomena are common now. With the continuous increase of divorced families, there are more and more children from divorced family, which does not only involve the personal right, property right and other problems of parents, but also involve the children custody, especially the custody problem of minor children. Therefore, it is very important to pay attention to develop the liability of custody for minor parents from divorced family.

\section{Current situation and problems of custody of minor children from divorced family}

\section{(I) Current situation}

In the Marriage Law of the People's Republic of China, the custody of parents for minor children is not clearly pointed out, but Article 36 of Marriage Law specifies: "The relation between parents and children cannot be eliminated because of the divorce of parents. After divorce, parents still have the rights and obligations of custody and education for their children." For divorced family, the children can live with either their father or mother. Although parents still have the custody of their children, their liabilities are different.

(II) Problems

1. Improper interest center

Peaceful divorce is rare in China and many people are completely isolated from each other all their lives after divorce as they fight one another fiercely in division of property and custody. Parents do not want to raise the children for the purpose of remarriage in the future or do not let the other party visit the children and infuse bad words against the other party to the children after getting the custody to leave bad influences on children. After divorce, the raising party forms a new family, in which the children may not be adaptive due to the change of family environment, thus affecting the healthy growth of children. To be good for the children, the raising party may not form a new family. As the single-parent family lacks of the love and education of the other party, the character of children has defects and the raising party has certain economic pressure. Upon the divorce of parents, parents often pay great attention to their interests and neglect that of children, 
thus affecting the healthy growth of children.

2. Disputes on cost of maintenance

After divorce of parents, the children will be raised by one party and the other party should pay the cost of maintenance. Generally, the cost of maintenance is determined according to the salary income of the other party upon divorce. During children raising, the increase of educational expense and price and other problems may occur. Upon divorce, to strive for the custody, the raising party often requires no or less cost of maintenance, but fails to meet the normal living need of children in the real life due to the great economic pressure, thus causing some disputes and bad influences on children.

3. Tort problem

In the real life, for the tort cases of minor children from divorced family, the non-raising party will refuse to bear the tort compensation on the ground that the raising party fails to fulfill its liability of custody to cause bad problems of children when the raising party asks the non-raising party to bear the tort compensation, thus causing some disputes and leaving shadow that cannot be erased in the growth of children.

\section{Cause for custody problem of minor children from divorced family}

(I) Unclear custody principles

In the Marriage Law, the custody principle of minor children from divorced family is not clearly pointed out, thus affecting the growth of minor children. The custody principle of minor children from divorced family in China is mainly joint custody, for which the parents can have the custody right of children after divorce. The joint custody is the joint cultivation of children by parents and an ideal living state, which consolidates the family love and plays a positive role in the all-around and healthy development of children's character. It can be seen that the joint custody is better than sole custody. In the real life, the parents cannot live with the children after divorce and most of the parents cannot keep a good relation after divorce in China, so the divorced parents have a great disagreement in children's life, education and other aspects, which imposes certain influence on the healthy growth of children. At this stage, many countries all over the world put forward the dual-track approach of joint custody and sole custody. The joint custody principle in China cannot meet the need of actual situation. In China, parents who are willing to adopt joint custody and raise the children in turns exercise joint custody and parents who are not willing to adopt joint custody exercise sole custody.

(II) Custody of children during lactation period by mother and custody by father under other special circumstances

During legislation, the children are raised by mother considering the infants' need of mother; however, the father plays an irreplaceable role in the growth of children, so a full consideration must be made. At present, the custody of minor children from divorced family in countries all over the world is subject to the principle of following the best interests of minor children. In China's laws, there is no clear "minor children's best interest" principle and the "parents-based" principle is followed. The "parents-based” principle and "minor children's best interest” principle differ greatly.

\section{Perfect the liability of custody for minor children from divorced family}

(I) Establish sound custody system of minor children from divorced family

To effectively solve the custody problem of minor children from divorced family, attention should be paid to the establishment of custody system to prevent and solve the disputes on minor children. It is required to develop the custody system with regard to the minor children from divorced family in the Marriage law, including the division of rights and obligations and way of performance and realize the docking of system and civil law system to better fulfill the liability of custody and promote the healthy growth of minor children.

(II) Establish the custody principle

Upon the divorce of parents, the joint custody or sole custody is determined according to the 
negotiation of parents on the basis of guaranteeing the interests of minor children. Without any agreement, the custody mode should be judged by the court according to the "minor children's best interest" principle to confirm the parents' liability of custody for minor children and define the custody scope and contents. For example, considering the needs of minor children, the custody is given to one of parents, which does not only respect the will of both parties, but also is an important way to meet the living needs of minor children. This is a reasonable, scientific and effective custody principle. In addition, the interests of minor children should be fully considered in reviewing the divorce agreement and the agreement that damages the interests of minor children cannot be approved and submitted to the court for handling, which cannot only guarantee the legitimate interest of minor children, but also reduce the burden of court proceeding.

(III) Establish the sound "minor children's best interest" principle

The core content of minor children's best interest principle is to maximize the interests of minor interests and give the corresponding legal protection to minor children as individuals. The regarding of minor children's best interest principle as the basic principle of minor children custody conforms to the humanistic spirit of custody law. However, the concept of "minor children's interests" is abstract and it is hard to judge the interests of minor children. In addition, the interests of minor children do not only include the short-term interests and the future life of minor children must be predicted and analyzed to ensure the healthy growth of minor children. An unified standard cannot be formulated strictly, but a basis can be provided and a standard can be formed considering the different family. The minor children's best interests include the following points: first, age, emotion and will of minor children; second, watcher of the life of minor children; third, adaptation of minor children to family, residence and school; development needs of minor children in physical, education, psychology and other aspects; fifth, time of minor children living with parents; sixth, economic level of parents; seventh, liability of custody of parents and parents' ability to care, guide, educate and affect the minor children; eighth, physical condition of parents and the influences of their behavior and habits on minor children; ninth, motivation of parents striving for custody etc.

(IV) Determine the cost of maintenance

In determining the cost of maintenance, the economic level of parents, living level and education of minor children in the non-divorced state must be fully considered. For adult children accepting higher education, parents cannot pay the educational expense in case of no economic capability, but should bear the raising fee in case of any ability.

(V) Build marriage and family consulting agency

In building the marriage and family consulting agency, the government can use the media for publicity and education, conduct training education of parents and minor children, effectively settle the contradictions between couples, solve the growth problem of minor children, eliminate the bad influences of parent contradiction on minor children, follow and know the custody, education and psychology of minor children after divorce of parents, establish the files of minor children from divorced family, record the learning, life and other information of minor children in details and solve problems immediately if any to ensure the healthy physical and mental growth of minor children.

(VI) Perfect the custody content and mode of minor children from divorced family

The custody content of minor children from divorced family mainly includes personal right, property right and legal agent right, in which the personal rights are daily life care right, education right, residence designation right, punishment right, identity and behavior agency right, vocational permit right, identity and behavior approval right and children delivery right; the property rights are approval right, agency right and property management right in the property law; and the legal agent rights are mainly reflected in the personal right and property right.

With the continuous development of the society, to effectively guarantee the healthy development of minor children from divorced family, the custody content of minor children from divorced family must be refined, mainly embodied in the personal right and property rights: first, care of physical condition and daily life; second, living together; third, education and cultivation; fourth, reasonable punishment right; fifth, agency of civil action; sixth, property management and 
protection; seventh, coming of property of person under guardianship under the supervision of relevant supervision institution; eighth, disposal of property of person under guardianship with the approval of supervisor of guardianship; ninth, regular report of the personal, property and educational condition and others aspects of person under guardianship to the supervisor of guardianship; tenth, handover of the property and other relevant information to the person under guardianship or guardian successor upon the expiration of guardianship.

The custody mode should be specified clearly to ensure the fulfillment of liability of custody. First, at the personal aspect, the name right, identity and behavior agency right, identity and behavior approval right of minor children should be determined by parents through negotiation. The agency rights include identity change, identity and behavior agency and identify approval, for which either party can exercise the custody right alone and the father or mother can exercise sole custody in case of any influence on the interests of minor children to protect the legitimate interests of minor children and maximize the interests of minor children. Second, at the property aspect, the use and benefits of the personal property of minor children should be guarded and the property is mainly managed by the raising party. At the same time, to avoid the abuse of the personal property of minor children, a reasonable and scientific restriction mechanism can be built combined with the actual situation to authorize the party that does not live together with the minor children to supervise the use of the personal property of minor children. If necessary, the personal property of minor children can be managed to protect the legitimate interests of minor children.

\section{Conclusion}

In conclusion, for the liability of custody of minor children from divorced family, attention must be paid to establish and perfect the laws and regulations to lay a solid foundation for exercising the custody. In exercising the custody, attention must be paid to the establishment of custody principle, the "minor children's best interest" principle must be followed, the marriage and family consulting agency must be built and the custody content and mode of minor children from divorced family must be perfected to ensure the implementation of liability of custody and promote the healthy growth of minor children.

\section{References}

[1] Shi Weimin. On Exercise of Custody of Minor Children from Divorced Family[J]. Lanzhou Academic Journal, 2010(08).

[2] Bai Xu, Gao Conghui. On Liability of Custody for Minor Children from Divorced Family[J]. The Guide of Science \& Education, 2014(26).

[3] Lou Qingzhi. Comparative Research on Right Exercise of Divorced Parents in China and US[D]. Zhengqiu University, 2010.

[4] Cai Jing. On Perfection of Legislation Concerning Minor Children Custody of Divorced Parents[J]. Law and Economy (Middle of This Month), 2010(7).

[5] Xue Fangqing. On Minor Children Custody System of Divorced Parents[J]. Journal of Heilongjiang Administrative Cadre Institute of Politics and Law, 2010(09). 